\title{
Translating Neuroethics: Reflections from Muslim Ethics
}

\section{Commentary on "Ethical Concepts and Future Challenges of Neuroimaging: An Islamic Perspective"}

\section{Ebrahim Moosa}

\begin{abstract}
Muslim ethics is cautiously engaging developments in neuroscience. In their encounters with developments in neuroscience such as brain death and functional magnetic resonance imaging procedures, Muslim ethicists might be on the cusp of spirited debates. Science and religion perform different kinds of work and ought not to be conflated. Cultural translation is central to negotiating the complex life worlds of religious communities, Muslims included. Cultural translation involves lived encounters with modernity and its byproduct, modern science. Serious ethical debate requires more than just a mere instrumental encounter with science. A robust Muslim approach to neuroethics might require an emulsion of religion and neuroscience, thought and body, and body and soul. Yet one must anticipate that Muslim debates in neuroethics will be inflected with Muslim values, symbols and the discrete faith perspectives of this tradition with meanings that are specific to people who share this worldview and their concerns.
\end{abstract}

Keywords Neuroethics · Muslim ethics · Islam · Islamic law · Islamic ethics · Neuroscience

Advocacy for the pulsation of arteries, I don't do If an eye cannot shed tears of blood, what's the point of blood anyway?

... These ideas, from the unseen, come to me The screeching of the nib, oh Ghalib, is actually the melody of the angel of revelation. Mirza Asadullah Ghalib (1989)

Ebrahim Moosa is professor of Religion and Islamic Studies at Duke University.

E. Moosa $(\bowtie)$

Department of Religion, Duke University, Durham, NC, USA

e-mail: emoosa@gmail.com 


\section{Introduction}

How do scholars engaged in the study of Muslim ethics deal with the emerging field of "neuro"-everything? I partially agree with Ramachandran (2011) who playfully labeled the enthusiasm for all things "neuro" as a kind of neurohype. Yet, any scholar, who wishes to remain current in the study of Muslim ethics, cannot suppress his or her curiosity to know which part of the brain regulates one's predisposition for 'hype'! Perhaps the anxiety not to be left behind on the knowledge-curve coupled with curiosity drives the urge among ethicists to behold the ethical frontiers of the 'neuro-dawn'.

Gazzaniga (2005) explains that ethical and moral discussions-right and wronginvolving the central nervous system are designated as neuroethics. It offers an opportunity to consider "how we want to deal with social issues of disease, normality, mortality, lifestyle, and the philosophy of living informed by our understanding of underlying brain mechanisms," he notes (Gazzaniga 2005). Both the ethics of neuroscience and the neuroscience of ethics, says Bird (2009), are the domains of neuroethics. This commentary anticipates questions in Muslim ethics in its encounter with aspects of neuroscience and the rise of a possible Muslim perspective on neuroethics. What this means, is that as a faith tradition Muslim somatic practices, beliefs, values and symbolism might cumulatively provide different meanings to the practice and application of neuroethics.

\section{Muslim Ethics}

Muslim ethics or Islamic ethics is derived from a religious tradition. As a religious tradition it meets the same fate that other religious traditions suffer in their encounter with modernity and modern science namely, insoluble controversy about the compatibility between religious theologies and notions of modern science (Brooke 2010; Dixon et al. 2010; Stearns 2011; Yousif 2001). What also afflicts Muslim ethics is the overblown religion versus science standoff. What is clear is that knowledge of religion and knowledge of science each have a distinct epistemological architecture. Both cherish distinctive discursive practices, but each also sustains different presumptions, different horizons and different ends. And this is what is significant: the separate ways in which religion and science view the meaning and purpose of knowledge. Crucially, each attributes a different meaning to their respective truths.

One should keep in mind that knowledge in religious traditions is often linked to questions of salvation. This also gives such knowledge a different function, one that might often conflict with secular perspectives. Secular knowledge traditions have challenged religious worldviews and cosmologies with the presentation of new 'facts.' Scientific worldviews have also challenged, modified or displaced older religion-based cosmologies with their own equally complex 'fact-based' cosmologies. Some modern practitioners of religion, often theologians and ethicists, frequently attempt to reconcile the worldviews of religion and science by reconstructing the meaning and end of both science and religion in order to sustain 
a mutual harmony between the two (Brooke 2010; Hameed 2010). Others keep both domains, namely science and religion, strictly separate and view each as independent yet indispensable meaning-making systems. Hence, one can often find the worldviews of lived religious communities today to be akin to a mosaic where religious and scientific worldviews intersect, conflict and overlap, sometimes in admirable as well as confusing ways.

The question is: how do these discursive traditions-science and religionsucceed in becoming partially or fully coherent to their audiences? Empirically, they acquire coherence or incoherence in the lived practices, teachings and the social imaginaries of their respective communities (Taylor 2004). ${ }^{1}$ Culture, the meaningmaking dimension of life as inhabited by individuals, communities and societies, gives it coherence (Hamdy 2012). Devout individuals and faith-communities frequently encounter the narrative of science ranging from discussions about natural causation, evolution, and quantum mechanics to the insights of neuroscience in their lives, but they hear these narratives in mixed and unpredictable ways inflected with the background narrative of the religion to which they might subscribe. What really happens is that complex processes of meaning-making (culture) consciously and unconsciously occur through translation (Sewell 2005).

Faith communities partake in scientific worldviews, often on their own terms, much to the chagrin of some scientists. These communities realign, update and actually translate their theologies (or partial cosmologies) into an accessible language in order for their religious worldviews to cohere with newer scientific cosmologies (Dixon et al. 2010; Ghaly 2010). In other instances religious communities and individuals resist the updating and realignment of their religious traditions vis-à-vis science (Brooke 2010; Hameed 2010). Nevertheless, the outcomes of such cultural processes are hybrids and admixtures that periodically produce insoluble problems, but nevertheless remain part of the incompleteness as well as the productive flux of human existence (Moosa 2002, 2007, 2012). AlDelaimy (2012) anticipates encounters in Muslim ethics and neuroimaging and alerts readers to some concerns. The question is: how different is the challenge of neuroimaging for Muslim ethics compared to say the challenge that genetically modified (GM) foods poses?

A believer might be guided by science to embrace the virtues of organically grown food and purified water and consume both on the grounds of empirical and scientific reason. In fact, he or she might further validate their practice of a healthy diet on the grounds of faith teachings. These individuals might resort to a kind of reasoning that argues that organic food was what was described in their scriptures millennia ago when organic food was abundant in the first place. Moreover, faith communities often associate a religious teaching that encourages the consumption of things that are "good" and "wholesome" with healthy organically grown food. Then using the same rationale they would vehemently resist genetically modified (GM) foods.

\footnotetext{
1 Social imaginaries are the "ways people imagine their social existence, how they fit together with others, how things go on between them and their fellows, the expectations that are normally met, and the deeper normative notions and images that underlie these expectations (Taylor 2004)."
} 
In contrast, people in the same faith might also resort to notions of "good" and "wholesome" food only to justify and embrace GM foods. They view the highly nutritious "golden rice" as combating disease and as a life saving food for millions. This group values the modification of food and understands the process as compatible with their religious beliefs. In the language of Muslim ethics they will interpret GM foods to serve the public interest (mașlaha) (Moosa 2009) and they will argue that the potential good in GM foods outweighs the potential harm in it. On the other hand, those who oppose GM foods fear the unknown health risks it might pose to humans and therefore adopt a precautionary (ihtiyatt) ethical position. In other words, it is not only the facts that help individuals and communities make ethical decisions. Ethical temperament, their aspirations, worldview formation and more crucially, how the facts of science translate into their theological universes in the final instance determine their ethical choices. Finding the right ethical language to articulate their convictions is the easy part. What is harder to determine is why one group opts for the viewpoint of caution instead of being sympathetic to how GM foods serve the public interest.

One of the great challenges for ethical decision-making from the standpoint of religious ethics is to avoid instrumentalizing ethical teachings. In other words, making decisions should not be based merely on expedient common sense readings and face-value appreciation of ethical teachings, and then mechanically applying these conclusions to scientific developments. One also has to bear in mind that Islam's ethical teachings were construed in a world where the understanding of nature, the body and the cosmos was very different from the modern world that Muslims inhabit today. Some of the ethical rulings, even if derived from divinelyinspired teachings, are not omniscient since they were constructed by humans. They carry inherent limitations as teachings and as ethical constructs.

So Al-Delaimy's concerns (2012) about privacy and the potential disclosures and invasion of privacy that arises from the use of fMRI in neuroimaging are important considerations. Yet one has to ask whether the notion of 'privacy' that might be compromised in the context of homes and personal information is comparable to the 'privacy' that is compromised when a human body is examined and imaged. What is the difference between the privacy considerations when a physician discovers that a patient has HIV-AIDS or a sexually transmitted disease, and the information that a patient's neuroimaging would reveal? If these differences can be made more precise, then the ethical concerns about neuroimaging and privacy might be better addressed.

The following thought experiment might be useful. Would it be ethical to subject a terrorist-suspect who harbors crucial knowledge of a ticking-bomb to neuroimaging during interrogation in order to ascertain whether he or she conceals such information in order to prevent the carnage of innocents? Might neuroimaging not be a better alternative to gaining lifesaving information than subjecting a suspect to torture? So the question might be, but what about the ethical qualms about privacy? If it so happens that the neuroimaging in addition to revealing whether the suspect conceals vital information or not, also reveals that the suspect has undisclosed homosexual tendencies, then the ethical burden of confidentiality and privacy falls 
on the neuroscientist. The same privacy and confidentiality protocols that apply to the physician would apply here.

One should also be open to the possibility that new technologies and science might produce unprecedented kinds of 'facts' that would in turn elicit values that are very different when compared to earlier incarnations of those same values formed in a different context. Concepts of privacy will adapt to the constantly evolving environment and surroundings of human living. It can be envisaged that when society is exposed to greater levels of neuroimaging in everyday life, then the very idea of privacy will be altered and one need not be tethered to anachronistic older concepts of privacy.

In premodern times, blood at a crime scene provided very little help in terms of forensic science and in criminal investigation procedures. Today, blood samples and DNA provide the prosecution with a surplus of information about an accused, all of which might not be relevant to the crime, but is available nonetheless. That surplus information ought to be subject to existing privacy regulations. In order to avoid abuse and violation of privacy in neuroimaging, the ethical quandary can be resolved with new regulations and ethical guidelines to monitor and enforce privacy rules. There might be less need to outlaw the technology than to harness the use of the technology to regulation.

\section{Approaching Neuroscience}

So how do Muslim ethicists approach the great wonders, challenges and dilemmas that neuroscience brings? Needless to say, the topic generates many more questions than easy answers. At least some neuroscientists have been modest enough to acknowledge that some of the scientific breakthroughs remain tentative in their application and significance (Ramachandran 2011). To be an alarmist therefore would be unwise.

Muslim ethics is a polyhedron: a hybrid of different genres of literature. Among the many, fiqh is the foremost genre and a discipline: it is a set of duty-based rules or what some have called a version of deontological ethics that goes by the unhelpful moniker of "Islamic law." However, fiqh converses with other genres of literature, including a genre in self-formation called virtue ethics (Moosa 2005). Furthermore, knowledge of the humanities and culture all cumulatively contribute to theories in Muslim moral philosophy and theology. A popular theory frequently invoked in ethical practices these days is utilitarian (mașlaḥa and maqāșid) in its outlook. Here the ethicist tries to evaluate the good and harm in a practice and makes a judgment regarding how the public interest would be optimized in view of the five purposes of the Shari'a. The five purposes are to preserve religion, life, intellect, property and family (Kamali 2003).

Even experts of Islamic law called muftis, ayatollahs, shaykhs or the ulama in general, are not sufficiently alert to these multiple layers of discourse. Often they are steeped in the duty-based ethical discourse and provide solutions to questioners from this perspective. Few theorize or re-theorize the complex meta-issues involved 
in the encounter of Muslim ethics with new discoveries and experiences in bioethics and neuroscience, for example, or science in general. Nor do they contemplate how this new knowledge and experience might shed light on the ethical and juridical culture of contemporary Muslims. Nevertheless, these expert practitioners do, in an ad hoc and pragmatic manner, incorporate new knowledge into their rulings and decisions with minimal attention to theory and systemization (Al-Azmeh 1988). Even when Muslim experts claim to engage in ijtihād-independent thinking in ethics-they remain confined to the discourse of duty-based ethics and rely on some theory of utility. For this reason their ethical remedies are limited in scope.

Would neuroscience be able to shed light on the ways in which humans are culturally wired? At first blush it appears that neuroscience might promote neural reductionism, but on further investigation, in light of Muslim ethics, one realizes that instead, it highlights and enhances an understanding of the organic complexity of the human body. For instance, premodern Muslim ethical and philosophical discourses promote a distinct sense that people 'think' with their 'hearts' (Moosa 2005). The expression simply means that the process of thinking does not only involve the mind but also has an affective component. It is thus pleasantly surprising to learn that neuroscientists also do not reduce the brain to only chemical processes. Rather they talk more helpfully about the relationship between reason and emotion. In fact, it was insightful on the part of Antonio Damasio to note "emotion was in the 'loop of reason"' (Moreno 2002, p. 48). Patricia Churchland believes that while emotions and reason might be handled by different parts of the brain, "in neural reality, the two are probably part of a continuum" (Moreno 2002, p. 47). Yet, the relationship between the brain, body and mind remains a conundrum with a shift in the position of the mind-body dualism split (Damasio 2003). The solution that Damasio offers is to understand that "the mind arises from or in a brain situated within a body-proper with which it interacts; that due to the mediation of the brain, the mind is grounded in the body-proper; that the mind has prevailed in evolution because it helps maintain the body proper; and that the mind arises from or in biological tissue-nerve cells-that share the same characteristics that define the other living tissues in the body proper ... body, brain, mind are manifestations of a single organism" (Damasio 2003, p. 191, 195).

The map of matter provides the quantification of the mind or configures the source of reason or emotion. Yet, how does one account for the immateriality of consciousness? That is what the nineteenth century Indian poet, Mirza Ghalib alluded to in the lines cited in the epigraph (Ghalib 1989). Ghalib seems to be less interested in William Harvey's description of the systemic circulation of blood in the body and its properties. Rather, he thinks of blood and the body as the locus of emotion and feeling in the same way his younger contemporary, the American poet, Walt Whitman did. Furthermore, Ghalib says the inspiration of his poetry stems from a metaphysical or cosmological realm that provides density and depth to his consciousness. A material account misses the immateriality of consciousness and it is precisely this aspect that Ghalib rails against. The immateriality of consciousness is accented in religious beliefs, values and meanings and informs the social imaginary of religious communities. 


\section{Towards a Muslim Neuroethics?}

Debates in bioethics might illustrate how Muslim ethicists deal with some questions in neuroethics. Muslim ethical rulings on brain-death have prompted many questions especially about how Muslim ethicists perceive technology and medical protocols related to the body (Haque 2008; Paladin 1998). Muslim ethicists are divided on the validity of brain death as a new definition of death (Moosa 1999). Brain death departs from the cardio-pulmonary benchmarks that indicate death with the cessation of heartbeat and pulse. Islamic ethical teachings that deal with the end of life such as testimony, dividing estates, consent, etc., all hinge on those visible cardiopulmonary signs of death. A patient whose body pulsates while being on a ventilator but is declared brain dead by physicians throws a wrench into the inherited ethical imaginary-norms, values, images and symbols-of Muslim ethicists, especially those who approach ethics from a traditionalist perspective. Some Sunni and Shia authorities accept the new definition of brain death and the medical criteria that establish it (Sachedina 2009). However, dissenting Sunni and Shia jurists take the somatic features as evidence of life and thus disallow organ donation from brain dead patients (Sachedina 2009).

The main challenge for Muslim ethicists is a metaphysical one: death is when the spirit departs from the body. In a previous age an inert body with no pulse provided absolute certainty that the soul had departed. Modern medicine does not pronounce on the absence or presence of the soul. Instead, it translates the metaphysical question into a legal and moral question, as to whether the patient qualifies to be treated as a legal person namely, a living person. Without consciousness, responsibility and memory do humans qualify to be designated as living? Can neuroscience provide greater certainty on the question of the vital functions of the brain? In other words, can neuroscience prove to a certainty that some brain functions will not return to patients who have been declared brain dead? Some Muslim ethicists have raised concerns, and even cast doubt on the lack of watertight neurological criteria in matters of brain death and the absence of directions for clinicians (Padela et al. 2011).

If Muslim ethicists intensify their conversation with neuroethics, would they be heading in the same pessimistic direction that some philosophers and thinkers relying on neuroscience have arrived at with regard to the soul (Pinker 1999, 2002)? Science cannot judge the supernatural nor pronounce on metaphysical claims (Wolpe 2009). Yet neuroscientific advances on the neural nature of thought, emotion, intellect and memory could go several ways. Paul Root Wolpe, for instance, raises the possibility that neural insights could disprove the existence of the soul. But why could the research also not go in another direction? Perhaps neuroscience could refine metaphysical insights related to the soul. Would such inquiries reframe and translate inherited metaphysical imaginaries about the soul into a more accessible idiom for moderns? The possibility remains that with such reframing, the very idea of the soul could potentially take a different form with a distinctive narrative in the emerging social imaginaries of societies shaped by science and culture. 


\section{Conclusion}

There is a great deal of debate as to whether the facts of neuroscience can lead to values derived from those facts. Some hyper empiricists like E. O. Wilson have insisted that science is the solvent for everything, even religion, a claim that should be met with a good dose of skepticism (French 2011; Wilson 1998). Moral philosophers will indeed raise objections to the predilection to derive values from facts. On the other hand, to turn facts into values would be tantamount to reducing the complexity of human life to the culture of science, as if science is the only narrative that determines human flourishing. Therefore, locating the insights of science, in this case neuroscience, within the larger tapestries of human thought and culture ranging from the social sciences and humanities to the natural sciences will always be a salutary approach.

In the study of Muslim ethics the encounter with neuroscience could be illuminating if it is done in a robust, intelligent and non-instrumental fashion. Both alarmist reactions to neuroscience and apologetics favoring it should be avoided. Often theologians and pseudo-theologians use science, and perhaps now neuroscience, in order to prove the validity and the wisdom of their scriptures only to put on display the 'truth' of their respective faiths. Advocates of religion have a long history of trying to show how the teachings of the Bible and the Qur'an were validated by science. These pseudo-theologies are embarrassing for both serious scientists and theologians. Nor do such arguments advance the cause of either science or theology.

Can there be a Muslim perspective on neuroethics? It depends. While there is no such thing as 'Islamic' medicine, 'Islamic' science or 'Islamic' plumbing, there might be a history of science in Muslim societies, where the Islamic qualifier refers to the culture or civilization in which such science flourished. Yet, there is something called Muslim or Islamic medical ethics and Islamic architecture. Why? Ethics and architecture deal with the anthropology of a specific culture and its practices. There are certain values that are distinctly linked to a Muslim, Buddhist, Jewish or Christian ethical and symbolic system. These symbols and values effectively channel and determine the meaning of the facts of medicine, architecture and science for the practitioners of each faith. The language believers often use combines the mythical language of faith and the empirical language of science and medicine. Believers undertake chemotherapy as treatment and at the same time they pray for relief from disease-related suffering in mosques, temples and churches.

People of different faiths, tastes and values design their homes in particular ways so that they sleep at night with their heads or faces directed towards Mecca or Disneyworld. Buddhist and Christian architecture, too, fulfill different meanings and purposes in their design and construction. For conscientious Muslims and Christians, there is indeed something called a Muslim or Christian ethics of healing or aesthetics of space. This involves attitudes towards the body informed by certain discrete values with Islamic or Christian practices ranging from the end of life ethical rituals, to constraints on the use of certain types of medicine. For instance, Islamic teachings strongly proscribe the cremation of the human body. Muslims disagree about the extent of permissible use of porcine products and alcohol in 
medicines just as they disagree about the validity of brain death and organ transplantation. These disagreements and proscriptions have very little to do with the facts of these practices and have a great deal to do with how these facts translate into their respective worldviews and give specific meaning to their practices. Similarly, one can anticipate Muslim ethicists having a very engaged, if not spirited, conversation with neuroscience. One can have every confidence that the more productive aspects of neuroscience will enhance and deepen an understanding of Muslim ethics, and one can hope that, in time, it will generate a more nuanced and complex Muslim perspective on neuroethics.

Acknowledgments I would like to thank the co-editor-in-chief of this journal, Stephanie J. Bird for inviting me to contribute to this special issue and for the feedback and comments she and her guest editors Michael Kalichman and Dena Plemmons provided. All remaining errors are mine.

\section{References}

Al-Azmeh, A. (1988). Islamic legal theory and the appropriation of reality. In A. al-Azmeh (Ed.), Islamic law: Social and historical contexts (pp. 251-265). London: Routledge.

Al-Delaimy, W. K. (2012). Ethical concepts and future challenges of neuroimaging: An Islamic perspective. Science and Engineering Ethics, 18. doi:10.1007/s11948-012-9386-3.

Bird, S. J. (2009). Neuroethics. In L. Squire (Ed.), Encyclopedia of neuroscience (pp. 385-391). Oxford: Academic Press.

Brooke, J. H. (2010). Science and secularization. In P. Harrison (Ed.), The Cambridge companion to science and religion. Cambridge, New York: Cambridge University Press.

Damasio, A. R. (2003). Looking for Spinoza: Joy, sorrow, and the feeling brain. Orlando, Fla: Harcourt.

Dixon, T., Cantor, G., \& Pumfrey, S. (2010). Science and religion: New historical perspectives. Cambridge, New York: Cambridge University Press.

French, H. W. (2011). E. O. Wilson's theory of everything. The Atlantic, November. http://www.the atlantic.com/magazine/archive/2011/11/e-o-wilson-rsquo-s-theory-of-everything/8686/

Gazzaniga, M. S. (2005). The ethical brain. New York: Dana Press.

Ghalib, M. A. K. (1989). Divān-i Ghālib. Lahore: Ferozsons.

Ghaly, M. (2010). Human cloning through the eyes of Muslim scholars: The new phenomenon of the Islamic international religioscientific institutions. Zygon, 45(1), 7-35.

Hamdy, S. (2012). Our bodies belong to God: Organ transplants, Islam, and the struggle for human dignity in Egypt. Berkeley: University of California Press.

Hameed, S. (2010). Evolution and creationism in the Islamic world. In G. N. Cantor, T. Dixon, \& S. Pumfrey (Eds.), Science and religion: New historical perspectives (pp. 133-152). New York: Cambridge University Press.

Haque, O. S. (2008). Brain death and its entanglements: A redefinition of personhood for Islamic ethics. Journal of Religious Ethics, 36(1), 13-36.

Kamali, M. H. (2003). Principles of Islamic jurisprudence. Cambridge, UK: Islamic Texts Society.

Moosa, E. (1999). Languages of change in Islamic law: Redefining death in modernity. Islamic Studies, $38(3), 305-342$.

Moosa, E. (2005). Ghazali and the poetics of imagination. Chapel Hill, NC: University of North Carolina Press.

Moosa, E. (2007). Neuropolitics and the body. In G. Ter Haar \& Y. Tsuruoka (Eds.), Religion and society: An agenda for the 21st century (pp. 47-59). Leiden, Boston: Brill.

Moosa, E. (2009). Genetically modified foods and Muslim ethics. In C. G. Brunk \& H. Coward (Eds.), Acceptable genes? Religious traditions and genetically modified foods (pp. 135-157). Albany: State University of New York Press.

Moosa, E. (2002). Interface of science and jurisprudence: Dissonant gazes at the body in modern Muslim ethics. In T. Peters, M. Iqbal, \& S. N. Haq (Eds.), God, life, and the cosmos: Christian and Islamic perspectives. London: Ashgate. 
Moosa, E. (2012). Muslim ethics and biotechnology. In J. W. Haag, G. R. Peterson, \& M. L. Spezio (Eds.), The Routledge companion to religion and science (pp. 455-465). New York: Routledge.

Moreno, J. (2002). Gaging ethics. In S. Marcus (Ed.), Neuroethics: Mapping the Field Conference Proceedings, May 13-14, 2002, San Francisco, California, (pp. 34-60). New York: Dana Press.

Padela, A. I., Shanawani, H., \& Arozullah, A. (2011). Medical experts and Islamic scholars deliberating over brain death: Gaps in the applied Islamic bioethics discourse. The Muslim World, 101(1), 53-72.

Paladin, A. (1998). Ethics and neurology in the Islamic world. Continuity and change. The Italian Journal of Neurological Sciences, 19(4), 255-258.

Pinker, S. (1999). The blank slate, the noble savage, and the ghost in the machine, The Tanner Lectures on Human Values, delivered at Yale University April 20 and 21, 1999. http://tannerlectures. utah.edu/lectures/documents/pinker00.pdf.

Pinker, S. (2002). The blank slate: The modern denial of human nature. New York: Viking.

Ramachandran, V. S. (2011). The tell-tale brain: A neuroscientist's quest for what makes us human. New York: W. W. Norton.

Sachedina, A. A. (2009). Islamic biomedical ethics principles and application. Oxford; New York: Oxford University Press.

Sewell, W. H., Jr. (2005). The concept(s) of culture. In G. M. Spiegel (Ed.), Practicing history: New directions in historical writing after the linguistic turn (pp. 76-95). New York: Routledge.

Stearns, J. (2011). Writing the history of the natural sciences in the pre-modern Muslim world: Historiography, religion, and the importance of the early modern period. History Compass, 9(12), 923-951.

Taylor, C. (2004). Modern social imaginaries. Durham, London: Duke University Press.

Wilson, E. O. (1998). Consilience: The unity of knowledge. New York: Knopf.

Wolpe, P. R. (2009). Religious responses to neuroscientific questions. In J. Illes (Ed.), Neuroethics defining the issues in theory, practice, and policy (pp. 289-296). Oxford: Oxford University Press.

Yousif, A. F. (2001). 'Islamic science': Controversies, influence and future possibilities for scientific education in Brunei Darussalam. Religious Studies and Theology, 20(1), 81-108. 